\title{
35. POLLEN ANALYSIS OF SOME SAPROPEL LAYERS FROM THE DEEP-SEA FLOOR OF THE EASTERN MEDITERRANEAN
}

\author{
Martine Rossignol-Strick, Laboratoire de Palynologie, Museum National d'Histoire Naturelle, Paris
}

\section{INTRODUCTION}

Presented here are the results of a palynological investigation of pollen and Dino flagellates in seven samples taken from four different locations on the deep sea floor of the eastern Mediterranean during Leg 13 of the Deep Sea Drilling Project, August-October 1970. For this preliminary study of the cores of this leg, samples were chosen only from selected levels of dark, organic-rich mud. (Table 1).

Two types of lithologies were examined: one, consisting of redeposited clay and silt (terrigenous) from sedimentary provinces characterized by downslope and crossslope sediment distribution (that is, turbidity currents and geostrophic circulation); and the other, containing predominantly biogenic components derived from purely pelagic sedimentation. For the latter, we chose finely laminated sapropels formed during periods of intermittent basin-wide stagnation since these layers make excellent repositories for organic trace material. In addition, the redeposited materials were selected at levels where the final deposition occurred either in an euxinic environment, or consisted of components which had previously been deposited in such an environment.

Pollen from the most recent $(\approx 7000-9000$ years B.P. $)$ period of stagnation has been analysed in samples from the seabed near the Island of Crete (M. Rossignol and L. Pastouret, 1971). Investigations of surface sediments in short cores have been reported by Koreneva (1969) and Vronsky and Panov (1963).

Additional samples from deeper levels in Quaternary sections of piston cores from the Robert D. Conrad cruise 9 in 1965 (Lamont-Doherty Geological Observatory of Columbia University) are now being analysed.

The materials discussed here come from four drilling locations (Figure 1), namely Site 125 on the Mediterranean Ridge in the Ionian Basin; Site 128 in the Hellenic Trench, Ionian Basin; Site 130 from the Mediterranean Ridge in the Levantine Basin; and Site 131A on the lower Nile Cone, Levantine Basin.

The Mediterranean Ridge sites are now isolated above the level of clastic sedimentation arriving onto the abyssal plains from the continents. Pelagic sedimentation at Site 125 has been continuous throughout the last four million years (see Chapter 47), whereas, at Site 130, it has only replaced predominantly terrigenous sedimentation in the last few hundred thousand years (see Chapter 25).

The Nile Cone and Hellenic Trench sites are at localities directly reachable by downslope transport from Africa and Europe respectively.

\section{SAMPLE PREPARATION}

Moist samples of a few cubic centimeters volume were first weighed and then immersed in hydrochloric acid. After twenty minutes the acid was diluted with distilled water, and then after one and one half to two hours time for settling, the liquid was decanted. The residue was subsequently soaked in 52 degree technical hydrofluoric acid and left to react for 24 hours. The preparation was then diluted with distilled water and decanted. After this, 50 percent $\mathrm{HCI}$ was added, left about half an hour, diluted and then decanted again. The samples were washed once more and then boiled for 3 to 5 minutes with 10 percent potassium hydroxide. This was followed by washing in a centrifuge several times. This last reaction was repeated up to three times, depending upon the amount of aggregates of amorphous organic matter still not dissolved. A Luber reaction was performed when the organic matter was too abundant (mixture of $5 \mathrm{cc} \mathrm{HNO}_{3}$ with a few drops of $\mathrm{HCI}$, cold, for 2 or 3 minutes, and agitated with glass rods). The samples were finally washed by centrifuging, mounted in glycerin (to which was added a crystal of phenol) and sealed between slide and cover glass $(22 \times 40 \mathrm{~mm}$.) with Glyceel.

\section{DESCRIPTION OF THE POLLEN CATEGORIES}

The pollen specimens recovered in the drill cores are subdivided into several groups of trees, shrubs, grasses, hydrophytes, Pteridophytes, tropical trees and grasses, and others undetermined. The raw pollen countings for each sample investigated are listed in Table 2 and the percentages of each group in the total pollen sum are indicated in Table 3.

\section{Mediterranean Trees}

An analysis of the pollen countings shows that two main types of trees, Quercus and Pinus are represented in similar relative proportions. Along with Cedrus, Olea, and to a lesser extent, Pistacia, these trees indicate a mediterranean environment with a two-season year consisting of cool humid winters and hot dry summers accompanied by a rainfall of from 400 to 1200 or more millimeters per year. Rainfall is mostly limited to the winters with occasional summer rains at high altitudes.

Cedrus requires cold and sunny days in the winter, which often occur at high altitude. Cedrus is found in widely separated locations: in Morocco in the Atlas, in Lebanon, south Turkey and Cyprus, and in the Himalayas. The respective adaptations of Mediterranean Pinus, $P$. 
TABLE 1

Sample Inventory

\begin{tabular}{|c|c|c|c|c|c|c|c|c|c|}
\hline Location & Latitude & Longitude & \begin{tabular}{|c} 
Water \\
Depth \\
$(\mathrm{m})$
\end{tabular} & $\begin{array}{c}\text { Sample } \\
\text { Depth } \\
\text { (m) }\end{array}$ & Core & Section & $\begin{array}{c}\begin{array}{c}\text { Sample } \\
\text { Interval } \\
(\mathrm{cm})\end{array} \\
\end{array}$ & & Distance from Land \\
\hline $\begin{aligned} \text { SITE } 125 \text { - } & \text { Mediterranean } \\
& \text { Ridge } \\
& \text { Ionian Basin }\end{aligned}$ & $34^{\circ} 37.5^{\prime} \mathrm{N}$ & $20^{\circ} 25.8^{\prime} \mathrm{E}$ & 2782 & 208.0 & 3 & 5 & $57-58$ & $\begin{array}{l}\text { Black } \\
\text { sapropela }\end{array}$ & $\begin{array}{l}200 \mathrm{~km} \mathrm{~N} \text { of Cyrenaican } \\
\text { Coast, } 260 \mathrm{~km} \text { SW of Pelo- } \\
\text { ponnese (Cape Matapan), } \\
300 \mathrm{~km} \text { WSW of Crete, } 520 \\
\mathrm{~km} \text { SE of Reggio (Calabria). }\end{array}$ \\
\hline $\begin{aligned} & \text { SITE } 130 \text { - } \text { Mediterranean } \\
& \text { Ridge } \\
& \text { Levantine } \\
& \text { Basin }\end{aligned}$ & $33^{\circ} 36.3^{\prime} \mathrm{N}$ & $27^{\circ} 52.0^{\prime} \mathrm{E}$ & 2979 & $\begin{array}{r}52.7 \\
256.0\end{array}$ & 2 & 3 & $\begin{array}{l}73-74 \\
54-55\end{array}$ & $\begin{array}{l}\text { Jet black } \\
\text { sapropela } \\
\text { Finely lam- } \\
\text { inated black } \\
\text { clayb }\end{array}$ & $\begin{array}{l}300 \mathrm{~km} \mathrm{NW} \text { of Alexandria, } \\
250 \mathrm{~km} \mathrm{~N} \text { of African Coast, } \\
250 \mathrm{~km} \mathrm{~S} \text { of Rhodes, } 300 \mathrm{~km} \\
\text { S of Turkish Coast }\end{array}$ \\
\hline
\end{tabular}

\footnotetext{
${ }^{\text {a }}$ Pelagic sedimentation, predominantly biogenic components.

${ }^{b}$ Predominantly terrigenous components.
}

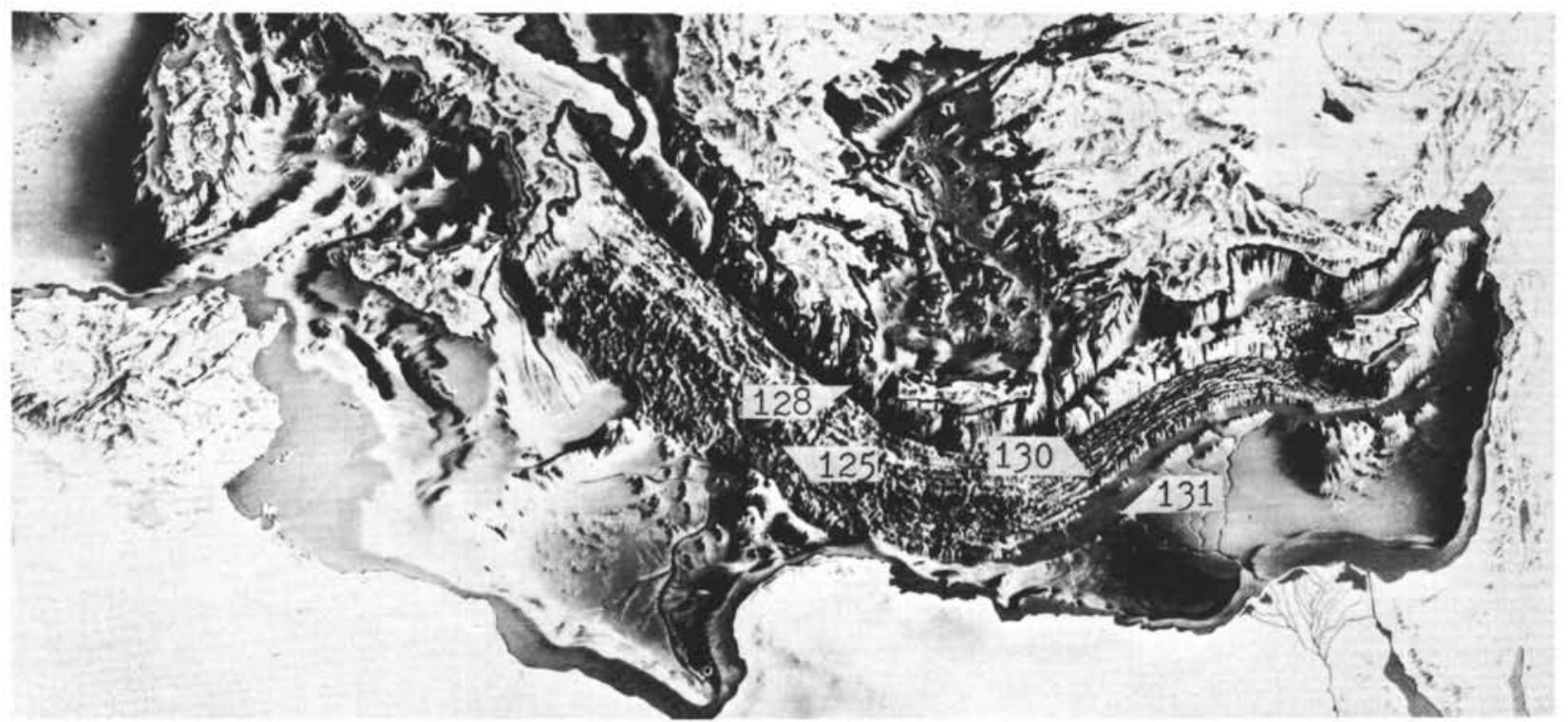

Figure 1. Physiographic setting of the Mediterranean drill sites where pollen was investigated.

brutia, $P$. halepensis, $P$. nigra, and Quercus are dependent upon soil and bedrock conditions, altitude, and variations of rainfall and temperature within the Mediterranean limits. Pinus here is mostly represented by $P$. diploxylon. However, in Sample 125-3-5, a low percentage (about 1\%) of the Pinus group consists of $P$. haploxylon, considered as a Tertiary relic. The Mediterranean trees are most highly represented in the samples close to Greece in the Hellenic Trench, but are second in abundance at the Mediterranean Ridge sites. They are poorly represented in samples from the Nile Cone.
Like the other ligneous groups described next, the Mediterranean tree pollens were probably first blown in to the sea from the Balkans and perhaps Italy, and then carried by currents to their final resting place. The dominant winds in the eastern Mediterranean basins are westerly, but in the summer, strong Etesian winds come from the north.

\section{Deciduous Thermophile Trees}

These trees require the same conditions as those existing today in the mountain ranges of the Balkans, the Caucasus, 
and Iran (on the northern slopes of the Elburz), and in the Hyrcanian forest) facing the Caspian Sea (the BalkanoCaucasian group). Most of them extend today to the forests of temperate European lowlands further North (Acer, Fagus, Tilia, Ulmus, Castanea, Fraxinus, most Betulaceae) and do not require as much warmth. Others were naturally restricted to southern European and S.W. Asian mountains, which appear to be a refuge for a Tertiary relict flora: Liquidambar, Zelkova, Juglans, Ostrya. Some are Tertiary relics which disappeared sometime during the Quaternary from this area and are to be found now either further east in Asia, (Pterocarya), or in America (Carya).

Pterocarya is found today both in the Far East and in the Near East: in the Caucasus, East Turkey, and North Iran, facing the Caspian Sea. It grows on river banks in lowlands, rarely above 300 meters (Tralau, 1963). Liquidambar still exists on the south shore of Turkey, as well as in China and North America (Kuprianova, 1960). Zelkova is now endemic in Crete, and occurs in the Caucasus, in Iran in the Hyrcanian forest, and in the Far East (Tralau, 1963). In the Caucasus, it does not grow higher than 300 meters above sea level, but in Iran, it reaches 1500 meters; the average temperature in the Caucasus is lower than in the Hyrcanian forest.

The requirements of these species are primarily, rainfall evenly distributed throughout the year, cold winters, and warm summers. The chronological implications of the presence of these Tertiary relics-Cedrus, Pterocarya, Carya, Liquidambar, Zelkova-will be discussed in further detail. They appear up to the lower Pleistocene in Italy.

In the pollen record, Pterocarya appears with 5, 6, or 7 pores, size 25 to $37 \mu \mathrm{m}$.

Carya has the typical 3-sub-equatorial pores in the same hemisphere.

The distinction between Zelkova and Ulmus is based on a thicker pore annulus and more conspicuous rugulate pattern in Zelkova than in Ulmus.

This group is never dominant, nor even second in importance, but is highly valuable for the purpose of dating. Its greatest abundance occurs in samples close to Greece, and it is almost completely absent in samples close to the Nile Delta.

\section{Other Trees}

The trees grouped here are neither deciduous (Tsuga, Abies) nor thermophiles (Betula). Tsuga is another Tertiary relic of the early Pleistocene of southern Europe. Abies exists today in the mountains of Greece and Turkey. Betula is found further north in Europe.

This group is present in very low percentages. However, it is highest in representation near Greece.

\section{Shrubs}

Ericaceae are common in the area north of the Mediterranean. Among Thymeleaceae, the most common, Thymelea hirsuta, is a desert shrub in sandy soil. It occurs here (128-3-6) in a station where the desert and steppe grasses are dominant.

Other prevalent shrubs include Ilex in Sample 131A-1-2 on the Nile Cone, Buxus cf. sempervirens, and Poterium spinosum. A single specimen of Myrica appears in Sample
131 A-4-2 and may have come from Uganda by way of the Nile. The highest representation of this group of shrubs occurs in the samples of pelagic sediment from the Mediterranean Ridge (130-2-3 and 125-3-5).

\section{Grasses: abundant}

The dominant grasses comprise four types: Graminae, Cyperaceae, Chenopodiaceae, and Artemisia. They represent steppe, saline desert, littoral sand belt and marshy environments.

Comparisons of the percentages of the grass group in the pollen sum, with the percentages of the other groups, and with those of each grass type in the group and in the pollen sum, reveal the following (Table 4):

1) The percentage of grasses in the pollen sum is usually highest in samples taken close to the Nile Delta, where the Mediterranean tree element is lowest. They are lowest, although still above 30 per cent, in samples from the Mediterranean Ridge where the Mediterranean tree element is highest.

2) Within the group, Graminae and Artemisia are present in the highest percentages. A comparison of the percentages of these two types in the pollen sum show that Graminae are highest in the samples of Nile River origin (131A-1-2, 131A-4-2, 130-5-2).

Artemisia is the most abundant grass in the pollen sum in the pelagic sediments of the Mediterranean Ridge and in the redeposited sapropels of the Hellenic Trench. In all of these, the Mediterranean arboreal element also reaches its maximum. In one of the northern samples, Artemisia even determines a strong dominance of the grass group in the pollen sum (128-3-6).

The high percentages of Graminae in the Nile transported sediment brings the grass group as a whole to much higher percentages than does Artemisia in most north samples, where it is counterbalanced by a large Mediterranean tree group.

3) There are two secondary members of the grass group, Chenopodiaceae and Cyperaceae. The distribution of Cyperaceae parallels that of Graminae: high in the same samples-and low in all the northern samples.

Chenopodiaceae variations are not as clear if only their percentages in the grass group are considered. However, their percentages in the pollen sum appear fairly constant in all the samples investigated, with the narrowest range of variation of all the grass types, this being from 4.4 to 13.5 per cent. Since their deposition does not seem linked to the Nile sedimentation, nor to the northern vegetation element, an independent origin for this family is suggested, namely, wind-transport from the North African or Middle Eastern deserts and/or from the Mediterranean shores.

These comparisons of percentages establish the geographical origin of each grass type. Graminae and Cyperaceae are transported by the Nile either from the Sudanese marshes of Bahr-el-Ghazal, or from the marshes of the Delta, or both. However, it is possible that part of the Graminae in the samples from the North, also have a northern origin. Artemisia, similar to the Mediterranean tree element, has a northern origin in the Balkanic and Turkish areas. Within this northern vegetation group, the importance of Artemisia appears to be inversely related to 
TABLE 2

Pollen Counts in the Seven Samples from the Eastern Mediterranean

\begin{tabular}{|c|c|c|c|c|c|c|c|}
\hline \multirow[b]{2}{*}{ Pollens } & \multicolumn{7}{|c|}{ Samples } \\
\hline & $\begin{array}{c}131 \mathrm{~A} \\
1-2\end{array}$ & $\begin{array}{c}131 \mathrm{~A} \\
4-2\end{array}$ & $\begin{array}{r}130 \\
2-3\end{array}$ & $\begin{array}{r}130 \\
5-2\end{array}$ & $\begin{array}{l}128 \\
3-5\end{array}$ & $\begin{array}{l}128 \\
3-6\end{array}$ & $\begin{array}{r}125 \\
3-5\end{array}$ \\
\hline \multicolumn{8}{|l|}{ Trees } \\
\hline Quercus & & & 326 & 22 & 150 & 170 & 141 \\
\hline Olea & & & 52 & 1 & 11 & 3 & 13 \\
\hline Phillyrea & & & & & & 1 & \\
\hline Oleaceae & 2 & 2 & 9 & & 9 & 3 & 22 \\
\hline Pistacia sp & & & & & & & 2 \\
\hline Pistacia lentiscus & & & 14 & & & & \\
\hline Pinus & 1 & 1 & 569 & 7 & 89 & 241 & 180 \\
\hline Cedrus & & & 11 & & 9 & 12 & 14 \\
\hline Total & 3 & 3 & 981 & 30 & 268 & 430 & 372 \\
\hline \multicolumn{8}{|l|}{ Deciduous thermophiles } \\
\hline Fagus & & & 2 & & & & 3 \\
\hline Tilia & & & 1 & & & & 3 \\
\hline Ulmus & & & 24 & 1 & 2 & 24 & 20 \\
\hline Zelkova & & & 9 & & & 6 & 11 \\
\hline cf Engelhardtia & & & & & & & 5 \\
\hline Liquidambar & & & & & & & 10 \\
\hline Carya & & & 3 & & & & 26 \\
\hline Pterocarya & & & 3 & & & 1 & \\
\hline Juglans & & & 1 & & & & \\
\hline Alnus & & & 22 & 2 & & 20 & 7 \\
\hline Carpinus & & & & & & & 3 \\
\hline Carpinus caucasica & & & 1 & & & & 4 \\
\hline Ostrya & & & 8 & & & 2 & 14 \\
\hline Corylus & & 1 & 19 & 6 & 6 & 4 & 24 \\
\hline Castanea & & & & & 1 & & 1 \\
\hline Fraxinus & & & 3 & & 1 & & 1 \\
\hline Total & 0 & 1 & 96 & 9 & 10 & 57 & 132 \\
\hline \multicolumn{8}{|l|}{ Others } \\
\hline Betula & & & 4 & 1 & 1 & 8 & 18 \\
\hline Abies & & & 1 & & 2 & 4 & 4 \\
\hline Tsuga & & & 1 & & & & 2 \\
\hline Total & 0 & 0 & 6 & 1 & 3 & 12 & 24 \\
\hline \multicolumn{8}{|l|}{ Shrubs } \\
\hline Ericaceae & & & 78 & 1 & 3 & & 36 \\
\hline Thymeleaceae & & & & & & 1 & \\
\hline Ilex & 1 & & & & & & \\
\hline Buxux sempervirens & & & & & & & 2 \\
\hline $\begin{array}{l}\text { Poterium spinosum } \\
\text { Myrica }\end{array}$ & & 1 & 14 & & 1 & 6 & \\
\hline Total & 1 & 1 & 92 & 1 & 4 & 7 & 38 \\
\hline \multicolumn{8}{|c|}{ Grasses } \\
\hline \multicolumn{8}{|c|}{$\begin{array}{l}\text { Dominant (Steppic, desertic } \\
\text { or littoral) }\end{array}$} \\
\hline Graminae & 247 & 213 & 306 & 285 & 11 & 58 & 141 \\
\hline Cyperaceae & 235 & 71 & 74 & 127 & 1 & 0 & 44 \\
\hline Chenopodiaceae & 73 & 17 & 235 & 58 & 45 & 298 & 116 \\
\hline Artemisia & 1 & 3 & 623 & 8 & 89 & 1226 & 214 \\
\hline Total & 556 & 304 & 1238 & 478 & 146 & 1582 & 515 \\
\hline \multicolumn{8}{|l|}{ Frequent } \\
\hline Compositae: & & & & & & & \\
\hline Liguliflores & 1 & 2 & 13 & & 4 & 12 & 9 \\
\hline Tubiflores & 2 & 5 & 80 & 9 & 8 & 24 & 24 \\
\hline Ephedra & & 2 & 15 & 3 & 2 & 43 & 13 \\
\hline Plantago & 5 & 3 & 25 & 7 & 1 & 7 & 33 \\
\hline Total & 8 & 12 & 133 & 19 & 15 & 86 & 79 \\
\hline
\end{tabular}


TABLE 2 - Continued

\begin{tabular}{|c|c|c|c|c|c|c|c|}
\hline \multirow[b]{2}{*}{ Pollens } & \multicolumn{7}{|c|}{ Samples } \\
\hline & $\begin{array}{c}131 \mathrm{~A} \\
1-2\end{array}$ & $\begin{array}{c}131 \mathrm{~A} \\
4-2\end{array}$ & $\begin{array}{l}130 \\
2-3\end{array}$ & $\begin{array}{c}130 \\
5-2\end{array}$ & $\begin{array}{c}128 \\
3-5\end{array}$ & $\begin{array}{r}128 \\
3-6\end{array}$ & $\begin{array}{l}125 \\
3-5\end{array}$ \\
\hline $\begin{array}{l}\text { Others } \\
\text { Borraginaceae } \\
\text { Campanulaceae } \\
\text { Caryophyllaceae } \\
\text { Centaurea } \\
\text { Cistaceae } \\
\text { Convolvulaceae } \\
\text { Cruciferae } \\
\text { Dipsaceae } \\
\text { Geraniaceae } \\
\text { cf. Galium } \\
\text { cf. Guttifere } \\
\text { Helianthemum } \\
\text { Labiatae } \\
\text { Lythraceae } \\
\text { Plumbaginaceae } \\
\text { Polygonaceae } \\
\text { Ranunculaceae } \\
\text { Rosaceae } \\
\text { Rumex } \\
\text { Sanguisorba } \\
\text { Solanaceae } \\
\text { Umbelliferae } \\
\text { Urticeae }\end{array}$ & 1 & 1 & $\begin{array}{r}1 \\
1 \\
1 \\
1 \\
1 \\
1 \\
13\end{array}$ & 1 & 3 & $\begin{array}{l}1 \\
1\end{array}$ & $\begin{array}{l}1 \\
4 \\
7 \\
6\end{array}$ \\
\hline Total & 1 & 5 & 35 & 1 & 9 & 24 & 27 \\
\hline $\begin{array}{l}\text { Hydrophytes } \\
\text { Nympheaceae } \\
\text { Typhaceae } \\
\text { Juncaginaceae }\end{array}$ & $\begin{array}{l}1 \\
8 \\
1\end{array}$ & 5 & 2 & 1 & 1 & 2 & $\begin{array}{l}2 \\
2\end{array}$ \\
\hline Total & 10 & 5 & 2 & 1 & 1 & 2 & 4 \\
\hline $\begin{array}{l}\text { Pteridophytes } \\
\text { Spores monoletes } \\
\text { Spores triletes } \\
\text { Riccia }\end{array}$ & $\begin{array}{r}10 \\
24 \\
8\end{array}$ & $\begin{array}{r}3 \\
27 \\
2\end{array}$ & 1 & $\begin{array}{r}3 \\
67 \\
2\end{array}$ & $\begin{array}{l}1 \\
1\end{array}$ & & $\begin{array}{l}1 \\
1\end{array}$ \\
\hline Total & 42 & 32 & 1 & 72 & 2 & 0 & 2 \\
\hline $\begin{array}{l}\text { Tropical Trees and Grasses } \\
\text { Podocarpus } \\
\text { Acacia } \\
\text { Acanthaceae } \\
\text { cf.Dicliptera } \\
\text { cf.Hypoestes } \\
\text { cf. Capparidaceae } \\
\text { Combretaceae } \\
\text { Euphorbiaceae } \\
\text { Euphorbia } \\
\text { Alchornea } \text { cf.cordifolia } \\
\text { cf. Tamarix } \\
\text { Moraceae } \\
\text { Ficus } \\
\text { Others }\end{array}$ & $\begin{array}{l}1 \\
3 \\
2\end{array}$ & $\begin{array}{l}1 \\
1 \\
1 \\
1\end{array}$ & $\begin{array}{l}3 \\
1\end{array}$ & $\begin{array}{l}1 \\
1\end{array}$ & & $\begin{array}{l}1 \\
1\end{array}$ & 1 \\
\hline Total & 9 & 7 & 9 & 2 & 0 & 2 & 1 \\
\hline Undetermined and undeterminable & 5 & 14 & 6 & 20 & 21 & 6 & 12 \\
\hline Total Counted (Pollen Sum) & 635 & 384 & 2599 & 634 & 475 & 2208 & 1224 \\
\hline
\end{tabular}

that of the Mediterranean trees. Chenopodiaceae, as an isolated group, seems to originate from the surrounding deserts.
Grasses: frequent

The group of grasses frequently encountered includes the Compositae (mostly Tubiflores), Ephedra and Plantago. 
TABLE 3

Percentages of Each Group in the Pollen Sum

\begin{tabular}{|c|c|c|c|c|c|c|c|}
\hline \multirow[b]{2}{*}{ Pollens } & \multicolumn{7}{|c|}{ Samples } \\
\hline & $\begin{array}{c}131 \mathrm{~A} \\
1-2\end{array}$ & $\begin{array}{c}131 \mathrm{~A} \\
4-1\end{array}$ & $\begin{array}{r}130 \\
2-3\end{array}$ & $\begin{array}{r}130 \\
5-2\end{array}$ & $\begin{array}{r}128 \\
3-5\end{array}$ & $\begin{array}{r}128 \\
3-6\end{array}$ & $\begin{array}{r}125 \\
3-5\end{array}$ \\
\hline Trees & & & & & & & \\
\hline Mediterranean & 0.5 & 0.8 & 37.8 & 4.7 & 56.4 & 19.5 & 30.4 \\
\hline $\begin{array}{l}\text { Deciduous } \\
\text { thermophile }\end{array}$ & 0.0 & 0.3 & 3.6 & 1.4 & 1.3 & 2.6 & 12.1 \\
\hline Others & 0.0 & 0.0 & 0.2 & 0.1 & 0.6 & 0.5 & 2.0 \\
\hline Shrubs & 0.1 & 0.3 & 3.5 & 0.1 & 0.8 & 0.3 & 3.1 \\
\hline Grasses & & & & & & & \\
\hline Dominant & 87.5 & 79.5 & 47.7 & 75.4 & 30.7 & 71.6 & 42.0 \\
\hline Frequent & 1.2 & 3.1 & 5.1 & 3.0 & 3.1 & 3.9 & 6.4 \\
\hline Others & 0.1 & 1.3 & 1.3 & 0.1 & 1.9 & 1.0 & 2.2 \\
\hline Hydrophytes & 1.6 & 1.3 & 0 & 0.1 & 0.2 & 0.2 & 0.3 \\
\hline Pteridophytes & 6.6 & 8.3 & 0 & 11.3 & 0.4 & 0.1 & 0.2 \\
\hline Tropical trees and grasses & 1.4 & 1.8 & 0.3 & 0.3 & 0.0 & 0 & 0.1 \\
\hline $\begin{array}{l}\text { Undetermined and } \\
\text { undeterminable }\end{array}$ & 1.0 & 3.6 & 0.2 & 3.1 & 4.4 & 0.3 & 1.0 \\
\hline A P & 0.6 & 1.4 & 45.1 & 6.3 & 59.1 & 22.9 & 47.7 \\
\hline N A P & 99.4 & 98.6 & 54.9 & 93.7 & 40.9 & 77.1 & 52.3 \\
\hline Pollen Sum & 635.0 & 384.0 & 2599.0 & 634.0 & 475.0 & 2208.0 & 1224.0 \\
\hline
\end{tabular}

TABLE 4

Percentages of Grass Types in the Grass Group and in the Pollen Sum

\begin{tabular}{|c|c|c|c|c|c|c|c|}
\hline \multirow[b]{2}{*}{ Pollens } & \multicolumn{7}{|c|}{ Samples } \\
\hline & $\begin{array}{c}131 \mathrm{~A} \\
1-2\end{array}$ & $\begin{array}{c}131 \mathrm{~A} \\
4-2\end{array}$ & $\begin{array}{r}130 \\
2-3\end{array}$ & $\begin{array}{r}130 \\
5-2\end{array}$ & $\begin{array}{r}128 \\
3-5\end{array}$ & $\begin{array}{r}128 \\
3-6\end{array}$ & $\begin{array}{r}125 \\
3-5\end{array}$ \\
\hline $\begin{array}{l}\text { Percentages of each grass } \\
\text { type in the grass group }\end{array}$ & & & & & & & \\
\hline Graminae & $44.0 \%$ & $70.0 \%$ & $25.0 \%$ & $60.0 \%$ & $7.5 \%$ & $4.0 \%$ & $27.0 \%$ \\
\hline Cyperaceae & 42.0 & 23.0 & 6.0 & 26.0 & 0.7 & 0.0 & 8.5 \\
\hline Chenopodiaceae & 13.0 & 5.6 & 19.0 & 12.0 & 31.0 & 19.0 & 22.5 \\
\hline Artemisia & 0.2 & 1.0 & 50.0 & 2.0 & 61.0 & 77.0 & 41.5 \\
\hline Sum of grasses & 556 & 304 & 1238 & 478 & 146 & 1582 & 515 \\
\hline $\begin{array}{l}\text { Percentage in total } \\
\text { pollen sum }\end{array}$ & $87.5 \%$ & $79.2 \%$ & $47.7 \%$ & $75.4 \%$ & $30.7 \%$ & $71.6 \%$ & $42.0 \%$ \\
\hline $\begin{array}{l}\text { Percentages of each grass } \\
\text { type in total pollen sum }\end{array}$ & & & & & & & \\
\hline Graminae & $38.9 \%$ & $55.5 \%$ & $11.8 \%$ & $45.7 \%$ & $2.3 \%$ & $2.6 \%$ & $11.5 \%$ \\
\hline Cyperaceae & 37.0 & 18.5 & 2.8 & 20.3 & 0.2 & 0.0 & 3.6 \\
\hline Chenopodiaceae & 11.5 & 4.4 & 9.0 & 9.1 & 9.4 & 13.5 & 9.5 \\
\hline Artemisia & 0.1 & 0.8 & 24.0 & 1.3 & 18.6 & 55.5 & 17.5 \\
\hline $\begin{array}{l}\text { Note from Table } 2: \\
\text { Per Cent of Mediterranean } \\
\text { trees in pollen sum }\end{array}$ & 0.5 & 0.8 & 37.8 & 4.7 & 56.4 & 19.5 & 30.4 \\
\hline
\end{tabular}

Their representation is greatest in the pelagic sapropels from the Mediterranean Ridge and the redeposited sapropels from the Hellenic Trench. They may belong to a belt of vegetation along the northern Mediterranean shore.

\section{Grasses: others}

As a whole this diverse group is also best represented in the sediments derived from Europe. However, two families,
Borraginaceae and partly Umbelliferae, are probably of southern origin.

\section{Hydrophytes}

These ubiquitous plants are more highly represented in Nile Cone samples. 


\section{Pteridophytes}

Pteridophytes are abundant only in the samples from the Nile Cone and the terrigenous black clays from Site 130. The trilete spores belong to 12 types, the monolete, to 2 . There are Pteris, Cyatheaceae, Selaginellaceae, Osmondaceae, Polypodiaceae. No attempt has been made to make more precise identifications. These same types, with about 30 more, have already been found off Palestine, in silts from the Nile Delta, and from Abou Simbel (M. Rossignol, 1969). Therefore, in our samples they can also be considered as Nile-transported. It is uncertain whether these spores come from the present fern vegetation around Lake Victoria (where the substratum is granitic) and were carried by the White Nile, or whether they are redeposited from the Mesozoic marine strata which, underlying the Basalt Trap in Ethiopia, are deeply cut by the Nile Gorge and its tributaries. The spores would then have been carried by the Blue Nile. The second hypothesis seems more probable, although comparative data are lacking.

\section{Tropical Trees and Grasses}

Although numerically not significant, the group of tropical trees and grasses is qualitatively very interesting. It appears to be more highly represented in the terrigenous samples from the Nile Cone: Podocarpus already has been found rather frequently off Palestine and in its Pleistocene coastal plain substratum (M. Rossignol, 1961, 1969). This small bladdered pollen has good buoyancy and may come from the forest belt of the east African equatorial mountains. Podocarpus pollen as found in the northern samples is probably a local Tertiary relic.

The Acanthaceae are also found off Palestine. They are abundant in the African savanna. Two genera are recorded here: cf. Dicliptera and cf. Hypoestes. The Euphorbiaceae have appeared here only as non-Mediterranean, tropical species: Alchornea cf. cordifolia (Van Campo, Palynologie Africaine, IV, PI. 96), and two tropical tricolporate Euphorbiaceae with strongly developed sunken rolled pore margins in equatorial contour; one of them is probably an Euphorbia.

The Capparidaceae are identified by their granulous endoaperture membrane.

The Ficus and Moraceae are triporate with a thin exine and no differentiated aperture margins, about $20 \mu \mathrm{m}$. Among the other tropical pollens is a stephanocolpate (II colpi) sub-prolate, $39 \times 36 \mu \mathrm{m}$, with a tectate scabrate exine and thick ectexine provided with large isolated columellae: cf. Bignoniaceae or Rubiaceae.

\section{Undetermined and Undeterminable Pollens}

Some small triporate pollens with a thin exine and non-annulated pores could not be satisfactorily attributed to Betulaceae, Halorhagaceae, Myricaceae, Casuarinales, Juglandaceae, Moraceae, Urticeae, Symplocaceae.

A very conspicuous tricolporate pollen, frequent in two samples, could not be identified (Plate 3, Figures 1-6, 10). It is sub-oblate having a 42 to $37 \mu \mathrm{m}$ equatorial diameter and a 39 to $35 \mu \mathrm{m}$ polar axis. The equatorial contour is angular, hexagonal with V-shaped planaperturate colpi and slightly convex, bow-shaped intercolpial planes. It has a large polar triangle (side, $10 \mu \mathrm{m}$ ). Exine pattern: the ectexine is composed of columellae united by their heads, and this tectum has a scabrate surface. The columellae have varying lengths and thicknesses. They are long and thick at the angles in equatorial contour and in the polar areas and are short and much thinner in an aureole around the apertures and in the middle of the intercolpial planes. In this latter location they delineate a circular area of thin exine easily folded on itself in equatorial contour, thus accentuating the angular outline. A very conspicuous characteristic is the apparent absence of any endexine in the white-light microscope; the foot of the columellae appears to rest on nothing. The colpi are slit-shaped without incrassate margins. There is a barely visible endoaperture: oval-shaped, lalongate, ill-defined at its meridian extremities; its existence would tend to prove, however, that of an endexine, at least in the endoaperture area. This very typical pollen appears overall 23 times: 4 in Sample 130-2-3, 19 in Sample 125-3-5. Both these samples have a northern pollen record, among which the deciduous thermophile trees and the Tertiary relics reach their highest percentages. This suggests that the pollen could also be a Tertiary ligneous relic. It is not impossible that it belongs to the Verbenaceae family, which is essentially tropical and sub-tropical.

\section{ANALYSIS OF THE NORTHERN POLLEN GROUP AND OF THE NILE POLLEN GROUP}

The seven samples are arranged in two groups according to the dominant origin of their pollens: northern or Nile. Only the pollens of northern origin are considered in the northern dominated samples, and of Nilotic origin for the Nile dominated samples. This allows us to establish more clearly the composition of each group at the time of its transport, before it became mixed with some elements of the other group during its final moment of deposition.

\section{The Northern Pollen}

For the group of northern pollen, we consider the arborescent pollen (AP) and the non-arborescent pollen (NAP) as two subdivisions. The NAP includes Artemisia, all the frequent grasses, and all the "other" grasses. We note that the Graminae and Cyperaceae have not been included in the northern group, although some of them may well have had an origin in Europe. The AP division includes the Mediterranean trees, the deciduous thermophile trees, and the "other" trees and shrubs. The countings and relative percentages of AP and NAP in the northern group are given in Table 5. The ratio of the AP to the sum AP + NAP is greater than 60 per cent in all samples but the redeposited sapropel of 128-3-6, and suggests a dense Mediterranean forest not far from the coast. The deciduous thermophile element may grow either in an upper altitudinal belt, or further to the north. Artemisia represents the highest percentage of the NAP: 79 per cent in 130-2-3, 79 per cent in 128-3-5, 92 per cent in 128-3-6, 67 per cent in 125-3-5, and the following percentages of the northern pollen sum, in the same order: 31 per cent, 23 per cent, 67 per cent, and 24 per cent. In Sample 128-3-6, a heavy increase of Artemisia (67\%) is coupled with a sharp decrease of the AP $(27 \%)$. In the two samples of Core 128 , there is clearly a trade off between Artemisia and the AP, their sum reaching 94 per cent in both samples. If this is not linked 
TABLE 5

Percentages of Arborescent Pollen (AP) and Non-arborescent Pollen (NAP) in the Northern Pollen Group

\begin{tabular}{|c|c|c|c|c|}
\hline \multirow[b]{2}{*}{ Northern Pollens } & \multicolumn{4}{|c|}{ Samples } \\
\hline & $\begin{array}{r}130 \\
2-3\end{array}$ & $\begin{array}{r}128 \\
3-5\end{array}$ & $\begin{array}{r}128 \\
3-6\end{array}$ & $\begin{array}{r}125 \\
3-5\end{array}$ \\
\hline $\begin{array}{l}\text { Sum of AP: } \\
\text { Medit. + Decid. therm. + others } \\
\text { + shrubs }\end{array}$ & 1175 & 281 & 506 & 584 \\
\hline $\begin{array}{l}\text { Sum of NAP: } \\
\quad \text { Artemisia } \\
\quad+\text { grass frequent } \\
+ \text { grass others }\end{array}$ & 791 & 113 & 1336 & 320 \\
\hline Sum of AP + NAP & 1964 & 394 & 1842 & 904 \\
\hline $\begin{array}{l}\text { AP X } 100 \\
\text { AP + NAP }\end{array}$ & $60 \%$ & $71 \%$ & $27 \%$ & $64 \%$ \\
\hline
\end{tabular}

only to deposition conditions, it could indicate a climatic variation resulting in the increase of the territory of Artemisia at the expense of the Mediterranean forest. It may be relevant here to recall that, in the pollen analysis of a Würmian core in Thrace, northern Greece, Wijmstra (1969) found that the cold phases were similarly marked by an increase of Artemisia at the expense of the Mediterranean forest. This suggests that the Pleni-Glacial Würm was locally a cool and dry phase rather than cool and humid. A similar conclusion has been reached by Van Zeist (1967) concerning a palynological investigation in the Zagros mountains of western Iran, where local conditions were considered as having a dominant influence. We suggest that the climatic limiting factor was humidity, rather than temperature.

It is quite apparent from this grouping of the northern pollen that the pelagic sapropel from the Mediterranean Ridge north of the Nile Cone at Site 130, in Core 2, Section 3 , owes more than 75 per cent of its pollen content to transport from the north. A very similar arborescent pollen ratio is found at the other Mediterranean Ridge location in the Ionian Basin (125-3-5) and again in a pelagic sapropel layer. In 125-3-5, the abundance of the now locally extinct Carya, Pterocarya, Tsuga points to a very early Pleistocene age.

The high pollen counts of the northern pollen group at these two topographically isolated locations argues for an efficient pelagic transport (wind and oceanic circulation) over moderately long distances in the open ocean.

\section{The Southern (Nilotic) Pollen}

The southern group, of dominant Nile origin, is represented in the finely laminated black and dark gray terrigenous clays from the Nile Cone (131 A-1-2; 131A-4-2) and the lower part of the sediment column from the Mediterranean Ridge (130-5-2) directly north of the Nile Cone. Because of the absence in these samples of arborescent pollen, the AP/NAP ratio is not significant. The pollen sum (see Table 6) only includes the pollen from Nile origin: Graminae, Cyperaceae, frequent grasses, hydrophytes, Pteridophytes, tropical trees and grasses.

The decreasing order of importance of the pollen groups remains constant in all three samples. Graminae and
Cyperaceae together account for 81 to 86 per cent of the entire southern group. The order of magnitude of each group does vary, but not very widely, except for Cyperaceae (from 21 to 42 per cent). This suggests, most likely, a fairly constant input to the sea by the Nile River.

\section{MECHANISMS OF TRANSPORT AND DISPERSAL OF THE POLLEN}

Three different processes involving the transport, dispersal and eventual sedimentation of the pollen are suggested from the observed distribution pattern in the four drillsites.

1. The first involves transport in a large stream such as the Nile River where the pollen becomes thoroughly mixed with terrigenous and other organic materials. The Graminae, Cyperaceae, Pteridophytes, hydrophytes, tropical trees and grasses enter the sea in suspension with the sediment discharge of the Delta. As observed by Emery et al. (1966) and Venkatarathnam and Ryan (1971), the Nile sediment crosses the Nile Cone and reaches the present Herodotus Abyssal Plain in nearbottom flows. Similarly, the pollen behaves as a benthic element.

The characteristic blue black Nile muds extend only as far as the northern terminus of the abyssal plain, and are absent in surface sediments on isolated topographic elevations on the lower Nile Cone.

The river-transport process is very efficient for long distances provided there is a pollen abundance in the catchment area. The pollen can be either contemporary with its transport, or it can be reworked from the sedimentary substratum cut by the upper valley erosion. Much pollen is probably destroyed during the transport. Upon reaching the open sea, the initial discharge may temporarily come to rest on the shallow shelf before eventual flushing downslope by slumping and turbidity currents. Thus, redeposited pollen of different stages is common in the southern (Nilotic) pollen group.

TABLE 6

Percentages of Graminae, Cyperaceae, Pteridophytes, Tropical Trees and Grasses, and Frequent Grasses in the Southern (Nilotic) Pollen Group

\begin{tabular}{c|c|c|c}
\hline \multirow{2}{*}{ Nile Pollens } & \multicolumn{3}{|c}{ Samples } \\
\cline { 2 - 4 } & $\begin{array}{c}131 \mathrm{~A} \\
1-2\end{array}$ & $\begin{array}{c}131 \mathrm{~A} \\
4-2\end{array}$ & $\begin{array}{c}130 \\
5-2\end{array}$ \\
\hline $\begin{array}{c}\text { Sum of Nile pollens: } \\
\text { Gram. Cyper. + grass frequent } \\
\text { + Pteridoph. + tropic. }\end{array}$ & 541 & 335 & 505 \\
\hline $\begin{array}{l}\text { Percentages: } \\
\text { Gram. } 100\end{array}$ & $45.0 \%$ & $64.0 \%$ & $56.0 \%$ \\
$\begin{array}{c}\text { Sum } \\
\text { Cyper. } \times 100\end{array}$ & $43.0 \%$ & $21.0 \%$ & $25.0 \%$ \\
$\begin{array}{c}\text { Sum } \\
\begin{array}{c}\text { Pteridoph. } \times 100 \\
\text { Sum }\end{array}\end{array}$ & $8.0 \%$ & $9.0 \%$ & $14.0 \%$ \\
$\frac{\text { Tropical } \times 100}{\text { Sum }}$ & $2.0 \%$ & $2.0 \%$ & $0.4 \%$ \\
$\frac{\text { Grass frequent } \times 100}{\text { Sum }}$ & $2.0 \%$ & $4.0 \%$ & $3.7 \%$ \\
\hline
\end{tabular}


2. A second mechanism primarily involves shortdistance wind-transport to the sea from the area of original vegetation, and then long-distance dispersal within the oceanic circulation system, mainly in surface currents. Here we surmise that the vegetation supplying the pollen probably lies within a few tens of kilometers from the coast. This pollen behaves essentially as a pelagic element; it floats longer and further if it has a high surface tension, and a low density. The northern pollen group, Mediterranean trees, deciduous thermophile trees, shrubs, Artemisia, and some others, are carried in this way. The evening land-breezes of the coastal belt, the westerly winds and the northern Etesian winds, probably play an important role. This transport pattern results in a decreasing gradient of sedimentation from the area of origin. Because there are no large streams from Greece, southern Italy or southern Turkey, the probability of reworked pollen into the northern group is low.

3. The uniform distribution of certain pollen types over large areas of the open-sea seems best explained by a third mechanism primarily involving long-distance wind-transport in the upper atmosphere. Such aeolian transport is invoked in order to provide the wide uniform dispersal of small sized non-bladdered pollens. It also happens to be responsible for the relatively high amounts of kaolinite sediments derived from the North African deserts and now found across the western Mediterranean Ridge and western Nile Cone (Venkatarathnam and Ryan, 1971). Only pollen which is very abundant in its area of production can be expected to be recognized as having this type of dispersal. This concerns the Chenopodiaceae, which probably come from the deserts of North Africa and the Middle East. It is the only pollen transport which can provide a similar deposition pattern on land.

Except in the case of bladdered pollens, the process of transport and deposition of pollen grains does not seem to be determined primarily by their intrinsic characteristics other than abundant production and a rather small size (the quasi-totality of non-bladdered recovered pollens are beiow 30 to $35 \mu \mathrm{m})$. Rather, they depend on the environment of the plants which produce them: geographical and topographical location, proximity of a stream, and atmospheric circulation.

The resultant marine pollen spectrum has the advantage of eliminating the distortions caused by the immediate vegetal environment in the pollen spectrum of a small body of water.

\section{ABSOLUTE FREQUENCIES}

Absolute frequencies represent the number of microfossils, pollens or Dinoflagellate cysts (Hystrichospheres), by gram of sediment. They are calculated as follows: $\mathrm{P}$ is the number of microfossils counted on a surface of $\mathrm{S}$ horizontal lines of the microscopic field at low scanning magnification (wide-field eye-piece 10X, objective 16X). Each line is $1 \mathrm{~mm}$ in diameter; there are 20 lines in each preparation (cover-glass of $22 \mathrm{X} 40 \mathrm{~mm}$ ). $\mathrm{N}$ is the number of microscopic preparations which may be made with all the residue of the sample. It is evaluated by the number of drops in the tube of residue (two drops are necessary for one preparation). This is measured by comparing levels of liquid in two similar tubes, one as witness, and the other with the residue. $\mathrm{W}$ is the weight in grams of the sediment sample. The absolute frequency $\mathrm{Fa}$ is calculated:

$$
\mathrm{Fa}=\frac{20 \mathrm{PN}}{\mathrm{SW}}
$$

For the three samples of Nilotic origin (131A-1-2, 131 A-4-2, 130-5-2), the pollan and Hystrichospheres absolute frequencies are rather low: between 800 and 3100 pollens, and 4 to 120 Hystrichospheres per gram of sediment.

This can be interpreted as the result of the fast accumulation rate of Nile mineral sediments. In fact, the two samples at Site $131 \mathrm{~A}$ are very sandy. The benthic pollen input is apparently diluted and moreover, may not have been very abundant originally. (This last concept is not easy to define; that is the number of pollen grains reaching a still surface unit of the water, stream or sea, per time unit).

For the other samples except Sample 128-3-5, the absolute frequencies of pollen and Hystrichospheres are much higher, being from 15200 to 32000 for pollen and 1250 to 5350 for Hystrichospheres. These high frequencies result mainly from a low sedimentation rate for its matrix, both mineral and organic; good conditions of preservation for pollen on the sea bottom after it settled there; and maybe also a more abundant pollen input. Pelagic pollen input is concentrated and also abundant (see above remark). All these values are much higher than those recorded in the Nile silt deposited offshore of Palestine during Pleistocene and Recent times (M. Rossignol, 1961, 1969) where the still high mineral sedimentation rate was combined with non-stagnant bottom conditions.

The absolute frequencies of Hystrichospheres, expressed as percentages of the absolute frequencies of pollen in the same sample, are relatively much lower in the sediments of Nile origin than in the pelagic sediments. This results from the conditions of formation of the Hystrichospheres. The planktonic motile stage of the Dinoflagellates lives in the superficial waters, where the waters of the Nile flood, less dense, less saline, than normal sea water, but richer in nutrients, circulate. The formation of the cyst is induced in these superficial waters, when the conditions of life are no longer favorable to the motile stage: less nutrients, change of salinity, overgrowth of the population; all events linked, in the south, to the periodicity of the Nile Flood. Genetic determinism may also have a role. Then, the cyst settles on the sea floor. Therefore, the induction of the cyst formation is linked to sea surface conditions, but their frequency per gram of bottom sediment, although not directly related to bottom topography, is influenced by the rate of mineral accumulation. This explains why the less diluted pelagic sediment of $130-2-3$, which is rich in Northern pollen, is also the richest in Dinoflagellate cysts.

In the sediments of Nile origin (131 A-1-2, 4-2, 130-5-2), the Dinoflagellate absolute frequencies increase with the distance from the Nile mouth, corresponding with less dilution of the cysts by mineral sedimentation. The Nile pollen absolute frequencies present a parallel trend in the same sediments. It is suggested that at the time of deposition of $131 \mathrm{~A}-4-2$, the mineral sedimentation rate was 
higher than for 131A-1-2, and maybe also the distance from the Nile mouth was smaller. In the south the absolute frequency of Dinoflagellate cysts results from the combined influences of superficial Nile waters and bottomtransported Nile sediments. In the northern samples of the Mediterranean Ridge (Site 125) and Hellenic Trench (Site 128), the presence of Dioflagellate cysts could be linked to the arrival of part of the less saline and nutrient-loaded waters of the Adriatic and Black Seas. It should be noted that the absolute frequencies of both pollen and Hystrichospheres in 128-3-5 are about 5 times lower than in 128-3-6. The ratios of Hystrichospheres to pollen are similar, however, being 8 and 9 per cent. This suggests that the mineral dilution is 5 times higher in 128-3-5 than in 128-3-6, a fact probably linked to the sedimentation condition of 128-3-5.

TABLE 7

Absolute Frequencies of Pollen and Hystrichospheres

\begin{tabular}{|c|c|c|c|c|c|c|c|}
\hline \multirow[b]{2}{*}{$\begin{array}{c}\mathrm{Fa} \\
\text { Microfossils }\end{array}$} & \multicolumn{7}{|c|}{ Samples } \\
\hline & $\begin{array}{c}131 \mathrm{~A} \\
1-2\end{array}$ & $\begin{array}{c}131 \mathrm{~A} \\
4-2\end{array}$ & $\begin{array}{c}130 \\
2-3\end{array}$ & $\begin{array}{r}130 \\
5-2\end{array}$ & $\begin{array}{r}128 \\
3-5\end{array}$ & $\begin{array}{r}128 \\
3-6 \\
\end{array}$ & $\begin{array}{r}125 \\
3-5 \\
\end{array}$ \\
\hline Fa pollen & 2600 & 800 & 32000 & 3100 & 3300 & 15200 & 21200 \\
\hline $\begin{array}{l}\text { Fa } \\
\text { Hystricho- } \\
\text { spheres }\end{array}$ & 60 & 4 & 5350 & 120 & 300 & 1250 & 2500 \\
\hline $\begin{array}{l}\mathrm{Fa} \\
\text { Hystr. } \\
\times 100 / \\
\text { Fa pollen }\end{array}$ & $2 \%$ & $0.5 \%$ & $17 \%$ & $4 \%$ & $9 \%$ & $8 \%$ & $12 \%$ \\
\hline
\end{tabular}

\section{POLLEN SEDIMENTARY CONDITIONS}

This paragraph summarizes for each sample, information from the previous paragraphs (Table 8 ).

\section{Samples 131A-1-2 and 131A-4-2}

The two samples from Site 131A, on the lower Nile Cone, have a distinct pollen content of Nile origin. Its ultimate source has not been ascertained. Grasses and Cyperaceae may come mostly from the Delta marshes, but also from the Bahr el Ghazal marshes further upstream. Pteridophytes may be recent, from the Lake Victoria area, or more likely, reworked from the Mesozoic substratum of the Ethiopian plateau. Also, they may be from any other eroded sedimentary area in the past catchment area. Only, the tropical element points clearly to a tropical African origin.
The pelagic transport of the northern pollens in the station area is prevented or extremely diluted by the enormous influx of the Nile waters. This should cast light on the water circulation in this area. Even some of the pollens which are northern in the pelagic samples from Site $131 \mathrm{~A}$ are more likely of Nile origin (Oleaceae, Ilex.).

\section{Samples 130-2-3 and 130-5-2}

Site 130 is located within a deformed belt of the Mediterranean Ridge, north of the Herodotus Abyssal Plain (see Chapters 11 and 25 of this volume). The two samples taken from the sediment column show a striking difference. The deeper sample (130-5-2) taken from the laminated black terrigenous clay, displays a dominant Nile influence, only slightly weaker than in the samples of Core 131A. The "northern" pollens, although very low, are higher than in Core $131 \mathrm{~A}$, and their variety points clearly to a northern origin. The upper sample (130-2-3) from the pelagic sapropel, shows on the contrary, a weak Nile influence and a much higher northern pelagic influence. The main part of this northern pollen fraction is composed of Mediterranean trees, with a very significant abundance of deciduous thermophile trees. The different pollen pattern of the two levels indicates that an important geological event has taken place at this drill site. It is suggested that the lower level, rich in terrigenous mud, shared the same sediment source as the Herodotus Abyssal Plain, namely, the Nile. Subsequently, an uplifting of the area prevented the arrival of the bulk of the Nile sediments and pollens, which apparently are only transported in deep water masses as benthic elements. On the subsequent uplifted zone, the pelagic pollen sedimentation of northern origin became dominant, as evidenced in the upper level. (For a further discussion see Chapter 48 of this volume). The sedimentation of the wind-transported Chenopodiaceae was not affected by changes of the bottom topography, nor by the origin of the water masses.

Table 9 compares the composition of the northern group (main components) in both samples from Site 130 and from Site 125, also on the Mediterranean Ridge. All three samples have the same dominant element (Mediterranean trees). The relative abundance of the deciduous thermophile tree group in relation to the northern pollen group is higher in the lower sample from Site 130, and very close to that observed at Site 125 .

The absolute frequencies also reflect the environment change. The lower level has a low absolute frequency similar to that at Site $131 \mathrm{~A}$ where it was attributed mostly to a high mineral rate of accumulation. The upper level has

TABLE 8

Percentages of the Pollen Geographical Groups in the Pollen Sum

\begin{tabular}{l|r|r|r|r|r|r|r}
\hline \multirow{2}{*}{\multicolumn{1}{c}{ Percent in Pollen Sum of: }} & \multicolumn{5}{c}{ Samples } \\
\cline { 2 - 8 } & $131 \mathrm{~A}-1-2$ & $131 \mathrm{~A}-4-2$ & $130-2-3$ & $130-5-2$ & $128-3-5$ & $128-3-6$ & $125-3-5$ \\
\hline Nile pollens & 86.6 & 88.5 & 14.9 & 80.0 & 3.1 & 2.9 & $15.7 ?$ \\
\hline Northern pollens & 1.0 & 3.4 & 75.5 & 7.6 & 83.0 & 83.0 & 74.0 \\
\hline Chenopodiaceae & 11.5 & 4.4 & 9.0 & 9.1 & 9.4 & 13.5 & 9.5 \\
\hline Undetermined + undeterminable & 1.0 & 3.6 & 0.2 & 3.1 & 4.4 & 0.3 & 1.0 \\
\hline Absolute frequency & 2600 & 800 & 32000 & 3100 & 3300 & 15200 & 21200 \\
\hline
\end{tabular}


TABLE 9

Percentage Composition of the Components of the Northern Pollen Group as Related to the Pollen Sum and to the North Pollen Group Itself

\begin{tabular}{|c|c|c|c|c|c|c|}
\hline \multirow[b]{3}{*}{$\begin{array}{c}\text { Main } \\
\text { Northern } \\
\text { Components }\end{array}$} & \multicolumn{6}{|c|}{ Samples } \\
\hline & \multicolumn{2}{|c|}{$130-2-3$} & \multicolumn{2}{|c|}{$130-5-2$} & \multicolumn{2}{|c|}{$125-3-5$} \\
\hline & $\begin{array}{l}\% \text { of } \\
\text { Pollen } \\
\text { Sum }\end{array}$ & $\begin{array}{l}\% \text { of } \\
\text { North } \\
\text { Pollen }\end{array}$ & $\begin{array}{l}\% \text { of } \\
\text { Pollen } \\
\text { Sum }\end{array}$ & $\begin{array}{l}\% \text { of } \\
\text { North } \\
\text { Pollen }\end{array}$ & $\begin{array}{l}\% \text { of } \\
\text { Pollen } \\
\text { Sum }\end{array}$ & $\begin{array}{l}\% \text { of } \\
\text { North } \\
\text { Pollen }\end{array}$ \\
\hline $\begin{array}{l}\text { Deciduous } \\
\text { Thermophile } \\
\text { Trees }\end{array}$ & 3.6 & 5.5 & 1.4 & 19.0 & 12.2 & 20.3 \\
\hline $\begin{array}{l}\text { Mediterranean } \\
\text { Trees }\end{array}$ & 37.8 & 57.8 & 4.7 & 63.5 & 30.4 & 50.6 \\
\hline Artemisia & 24.0 & 36.7 & 1.3 & 17.5 & 17.5 & 29.1 \\
\hline$\%$ Total & 65.4 & 100.0 & 7.4 & 100.0 & 60.1 & 100.0 \\
\hline
\end{tabular}

a very high absolute frequency which is common to almost all samples with dominant pelagic pollen.

The upper level is dated as early Pleistocene by some Tertiary relics in a mostly Pleistocene pollen record (Pterocarya, Carya, Tsuga). This post-dates the uplifting. The lower level is, therefore, either even earlier Pleistocene or late Pliocene.

It should be added that the three Nile-influenced samples have a common palynofacies: a very clean background, abundance of ligneous debris, and no amorphous organic matter left after the technical preparation. This is not the case of the other sapropels.

\section{Samples 128-3-5 and 128-3-6}

These two samples, which come from the floor of the Hellenic Trench west of Crete, have a very similar pollen spectrum. The dominant group is naturally the northern one with the same percentages in both samples. A very small group of Graminae and Cyperaceae appears. The term "Nile" pollens, as applied to them by analogy with the previous samples, could well be misleading because of the ubiquity of these families. But the tropical element is clearly missing, and the Pteridophytes are hardly represented. Variation in the Chenopodiaceae is only very slight. In the northern pollens, however, a significant shift has already been noticed in the percentages of Artemisia and the Mediterranean forest in the two samples. The phytogeographical and climatic interpretations will be discussed when more data will become available.

\section{Sample 125-3-5}

Site 125 was drilled in an elevated area of the Mediterranean Ridge providing undisturbed conditions of sedimentation for pelagic and aeolian elements. This sample has an original pollen spectrum with the Northern group dominating; the pelagic nature of this pollen group is thus confirmed.

\section{SURVEY OF THE UPPER TERTIARY THERMOPHILE RELICS IN SOUTH EUROPE (SPAIN, ITALY, THE BALKANS)}

The elements of middle-late Tertiary in northern Italy, which disappeared more or less early in Pleistocene or in late Pliocene (Ricciardi, 1965a), include: Symplocos, Sequoia, Nyssa, Pinus haploxylon, Cedrus, Picea, Tsuga, Abies, Taxodium, Sciadopitys, Podocarpus, Liquidambar, Carya, Pterocarya, Juglans, cf. Engelhardtia, Myrica. Lona (1963a) has discovered Cedrus, Sciadopitys, Podocarpus, Pinus, Keteleeria, Abies, in a middle-upper Pliocene marine clay near Parma. In the Tertiary of Boca-Maggiora, Piemonte, Lona (1963b) has also described Sequoia, Pinus haploxylon, Symplocaceae, Cyrillaceae, Clethraceae, Celastraceae, Sapindus, Castanea.

In northern Greece, the upper Pliocene flora of Almopias (Central Macedonia) (Mercier and Sauvage, 1965) includes Pinus haploxylon, Picea, Pseudolarix, Taxodiaceae, Pterocarya, Nyssapollenites, and deciduous thermophile trees, still existing in the Balkans, along with Mediterranean elements.

In Portugal (Diniz, 1967) the Pliocene appears with a dominant Mediterranean character (Quercus cf. ilex, Oleaceae, Ericaceae, Cistaceae), a dominance of Pinus diploxylon, and a well diversified herbaceous element, although the typically Tertiary trees and tropical elements are also present (Liquidambar, Carya, Sapotaceae, Symplocaceae, Palmae, Keteleeria, Pseudolarix, Tsuga, Cedrus, Podocarpus).

Typically Tertiary pollens persist in Italy during the lower to middle Pleistocene. This is later than those found in the Netherlands. In the Netherlands (Zagwijn, 1960), the complex Tsuga-Pterocarya-Carya has disappeared by the Cromerian which is correlated in Italy with the GunzMindel Interstadial. In Italy, in the upper part of the Leffe series, near Bergamo at the foothills of the Alps, the complex Carya-Pterocarya-Tsuga occurs as a whole until the Gunz I-II Interstadial (Lona and Follieri, 1958) after which it is dissociated. Carya and Pterocarya persist there abundantly through the Gunz-Mindel Interglacial and then sporadically until the end of the Mindel II-III Interstadial. Tsuga is found intermittently from the Gunz II-III Interstadial to the Mindel I-II Interstadial, where it becomes quite abundant again.

In the lower Leffe series (Lona, 1950), Liquidambar and Nyssa are very rare. They do not appear in the upper Leffe series. Zelkova does not range beyond the Gunz-Mindel Interglacial in the upper Leffe series.

In central Italy, some trees which disappeared earlier in northern Italy, persist until a later time (Zelkova, Liquidambar). Zelkova appears until perhaps the Riss in Cimini-Sabatini, (Ricciardi, 1961b), or even the Riss-Würm Interglacial near Mazzano, Rome (Napoleone and Follieri, 1967).

In the Leonessa basin, central Italy (Ricciardi, 1965b), Tsuga, Carya, Ptercocarya, Cedrus, and Pinus haploxylon are found in lower Pleistocene sediments and are correlated with the upper Leffe series. Liquidambar is present, but only in the lower quarter of the diagram.

In the basin of Gubbio, central Italy (Lona and Ricciardi, 1961), the sedimentary sequence is correlated with the upper Leffe series, and elements of the end of the Tertiary also persist: Pinus haploxylon, Picea type orientalis, Tsuga, Cedrus, Pterocarya, Zelkova, Liquidambar. The latter is much more abundant in Gubbio than in Leffe; it appears with a later local expansion. In Pietrafitta near 
Perugia (Ricciardi, 1961a), Liquidambar, Zelkova, Pterocarya, Tsuga are met in the Villafranchian. Indeed, Liquidambar has been with Zelkova, the most persistent Tertiary relic in Italy.

Some typically Tertiary elements do not appear in Italy in the lower Pleistocene. Nyssa shows only few pollens in the lower Leffe series and neither Sequoia nor Sciadopitys occur at all. The latest occurrence of Sciadopitys seems to be in the Apennines (Castell 'Arquato) in the PlioPleistocene marine deposits below the Calabrian and at the boundary between the Amphistegina layers and their underlying sandy clay layer, called Arquatian. At this level, it reaches an abundance of 6 per cent (Lona, 1962). Podocarpus appears last in the middle-upper Pliocene of Emilia (Lona, 1963a).

\section{CHRONOLOGY OF THE MEDITERRANEAN NORTHERN SAMPLES}

We can now attempt to date our Mediterranean samples of northern influence on the basis of their percentages of Tertiary relics. We must keep in mind that the further south in Europe we go, the later Tertiary thermophile relics persist. We must also take into account the distance between the north Mediterranean shores, the supposed place of origin of the pollens, and the location where the pollens finally settled.

The Tertiary relics in our Mediterranean samples appear with the percentages shown in Table 10. They include: Cedrus, Zelkova, cf. Engelhardtia, Liquidambar, Carya, Pterocarya, Juglans, Tsuga, and Podocarpus (north). Cedrus has been evaluated separately because its high percentages tend to mask the other trees.

\section{Sample 125-3-5}

The flora of Sample 125-3-5 is rich in Tertiary relics including: Carya, Pterocarya, Tsuga, Liquidambar, Zelkova, Pinus haploxylon, and cf. Engelhardtia. However, some typically Tertiary elements are missing, these are: Sequoia, Nyssa, Sciadopitys, and Picea of antique type, Taxodium. Therefore, a Tertiary age (Pliocene) is excluded. The Tertiary relics point to a lower Pleistocene age (Villafranchian). This is not incompatible with the abundance of the Mediterranean forest and the dominance of Artemisia. It also agrees with the biostratigraphic zonation based on nannofossils (see Chapter 33) and Foraminifera (see Chapter 46).

The Villafranchian age makes it very likely that the Podocarpus pollen comes from the north and not from the Nile.

\section{Sample 130-2-3}

Further to the east and slightly more to the south, Sample 130-2-3 shows the same Tertiary relics, although they are much less abundant. They are Tsuga, Pterocarya, Carya, Liquidambar, and Zelkova. The four Podocarpus pollens are probably also of northern origin, rather than Nilotic. The pollen spectrum has the same structure as 125-3-5, with fewer deciduous thermophile trees. The relative frequencies of the other groups are rather similar. The probable main source is the southern coast of Turkey.
TABLE 10

Percentage of Tertiary Relics in the Pollen Count of the Eastern Mediterranean

\begin{tabular}{|c|c|c|c|c|c|c|c|c|}
\hline \multirow{2}{*}{\multicolumn{2}{|c|}{$\begin{array}{c}\text { Per Cent of } \\
\text { Tertiary } \\
\text { Relics }\end{array}$}} & \multicolumn{7}{|c|}{ Samples } \\
\hline & & $\begin{array}{c}131 \mathrm{~A} \\
1-2\end{array}$ & $\begin{array}{c}131 \mathrm{~A} \\
4-2\end{array}$ & $\begin{array}{r}130 \\
2-3\end{array}$ & $\begin{array}{r}130 \\
5-2\end{array}$ & $\begin{array}{r}128 \\
3-5\end{array}$ & $\begin{array}{r}128 \\
3-6\end{array}$ & $\begin{array}{r}125 \\
3-5\end{array}$ \\
\hline In the & Total & 0.0 & 0.0 & 1.2 & 0.0 & 1.9 & 0.9 & 7.1 \\
\hline $\begin{array}{l}\text { Pollen } \\
\text { Sum }\end{array}$ & $\begin{array}{l}\text { Cedrus } \\
\text { Portion }\end{array}$ & & & 0.4 & & 1.9 & 0.5 & 1.1 \\
\hline $\begin{array}{l}\text { In the } \\
\text { Northern }\end{array}$ & Total & & & 1.6 & & 2.3 & 1.1 & 9.6 \\
\hline $\begin{array}{l}\text { Pollen } \\
\text { Group }\end{array}$ & $\begin{array}{l}\text { Cedrus } \\
\text { Portion }\end{array}$ & & & 0.6 & & 2.3 & 0.6 & 1.5 \\
\hline
\end{tabular}

The variety of Tertiary relics would suggest a similar lower Pleistocene age for this sample, but its percentage, much lower than in 125-3-5, may point to a somewhat later period. It could then be either late lower Pleistocene or early middle Pleistocene. The probability of a later age is also increased by the fact that Turkey is closer than southern Italy or Greece to the last and still existing refuges of the Tertiary thermophile relics, that is the Caucasus and northern slopes of the Elbourz facing the Caspian Sea. Therefore, the Tertiary relics may have remained later in Turkey than further west, and do support a more recent dating than would be probable in the west.

\section{Sample 130-5-2}

If there is no stratigraphical disturbance in Site 130 between Samples 5-2 and 2-3, an older age-maybe lower Villafranchian-should be attributed to the deeper 130-5-2 sample (its dominant Nile spectrum could not (yet) provide a dating clue). Table 9 shows, among the northern elements, the same percentages of deciduous thermophile trees as Sample 125-3-5.

\section{Sample 128-3-6}

The Teritiary element is greatly reduced in this sample, and half of it is represented by Cedrus, even though the station is located closer to the northern shore than Site 125. Besides Cedrus, only Zelkova and Pterocarya remain. The suggested age is middle or late Pleistocene. A postWurm sapropel, previously studied near southeast Crete and dated 7900 B.P. (M. Rossignol and L. Pastouret, 1971), also shows Cedrus, and a few pollens of Zelkova, Peterocarya, and Liquidambar.

Therefore, these trees persisted very late in this area. Their higher abundance in 128-3-6 than off southeast Crete suggests an earlier age - possibly the Mindel-Riss Interglacial.

\section{Sample 128-3-5}

Only Cedrus appears here. This sample is only slightly higher in the sequence than the previous one and therefore has an equivalent age. The absence here of the Tertiary relics, which still persist in the Holocene off southeast Crete, may not have a chronologic implication, but may only reflect sediment mixing during redeposition. 


\section{Dinoflagellates Cysts}

Twenty-three Dinoflagellate cysts species have been recorded. Their absolute frequency has been discussed above.

The most important group is Spiniferites furcata (Ehr.) O. Wetzel, S. mirabilis Rossignol. Operculodinium Wall appears with 5 species. Hystrichokolpoma rigaudae Deflandre and Cookson appears only in the two oldest samples of pelagic sediment from the Mediterranean Ridge (125-3-5 and 130-2-3), but Tuberculodinium van campoae (Rossignol) Wall is absent there.

A number of cysts of unknown systematic position appeared also. A detailed study of all the cysts is under way.

Some fresh water microfossils-Algae and uncertain affinities-occurred only in samples of Nilotic influence (Pediastrum [131A-1-2: 17; 131A-4-2: 32; 130-5-2: 12], Botryococcus [131A-1-2: 8; 131A-4-2: 3; 130-5-2: 11] Concentricystes rubinus Rossignol [131A-1-2: 2; 131A-4-2: 1]).

\section{SUMMARY}

Seven samples from four deep sea drilling sites in the eastern Mediterranean have been analysed for their pollen: two cores south and southwest of Greece, two north of Egypt.

The pollen spectra belong to two categories. One is dominated by the pollens coming from the northern shores of the Mediterranean; the other one is strongly characterized by pollen carried into the sea by the Nile River. In the first group, appear the following phytogeographical types: Mediterranean trees (Pinus, Quercus, Cedrus, Olea), deciduous thermophile trees (Fagus, Acer, Castanea, Alnus, Ostrya, Corylus, Carpinus, Carya, Pterocarya, Juglans, Engelhardtia, Liquidambar, Tilia, Ulmus, Zelkova, Fraxinus), other trees (Tsuga, Abies, Betula), shrubs (Ericaceae, Thymeleaceae, Buxus, Poterium, Myrica), and, among the herbaceous, Artemisia and an array of other families. The second group includes Graminae, Cyperaceae, Pteridophytes, hydrophytes, tropical trees and grasses. All the samples close to Greece and the upper sample of one of the cores from the Mediterranean Ridge north of the Nile Cone belong to the first group. The three other samples from the Ridge and the Nile Cone belong to the second group. Chenopodiaceae are equally present in all samples. They seem to result from a rather constant pollen rain on a large sea area after a long wind transport in the upper atmosphere. They may come from the steppe and desert regions of Africa and the Middle East.

The north-Mediterranean pollen may have been transported from their source area first by wind for a short distance to the nearby sea surface. Indeed, it is suggested that their source area is in the littoral zone including the first range of mountains in the back-country of southern Italy, Greece, and Turkey. Once arriving in the sea, they float in the superficial waters, and behave as pelagic elements. Their distribution in the sediments does not depend upon the bottom topography, but rather upon the distance from the shores and direction and magnitude of the currents and winds.
Conversely, distribution in the sediments of pollens from Nilotic origin is markedly influenced by the bottom topography. This suggests these pollens behave as benthic elements; transported in density currents of the deep water masses with the mineral-rich Nilotic sediments.

The number of pollens per gram of sediment is much higher for the pelagic pollens (up to 32000) than for the benthic pollens (average 2000).

A chronology has been made possible by the presenceor absence-in the samples of Northern origin, of pollens of trees which belong to a Tertiary relictual flora still living in Europe at the beginning of the Pleistocene: Pterocarya, Carya, Tsuga, Juglans, Liquidambar, Zelkova, Cedrus, Pinus haploxylon.

Nearly all of this flora progressively became extinct during the Quaternary. A Pliocene age is excluded by the absence of Nyssa and Sciadopitys. The proposed datations for the samples of northern influence extend from lower Villafranchian to the Mindel-Riss Interglacial. At least one of the Tertiary relics, Cedrus, and maybe also Zelkova, disappeared from the continent only in Holocene times, probably under the influence of man. The vegetal landscape in southern Italy, Greece and southern Turkey coastal areas was modified during the Pleistocene by the vertical shifting of the vegetal belts which appear in the pollen spectra. The Artemisia steppe, at the expense of the Mediterranean forest, is attributed mostly to an increased dryness, as is the progressive disappearance of the deciduous thermophile trees which did not find the refuge they would have needed to survive in the vicinity. High mountains further south, provided both humidity and warmth. A return of the Mediterranean forest in the youngest sample is attributed to a more humid phase. The previous disappearance of the deciduous thermophile trees prevented them from spreading again. The temperature increased slightly.

The pollen analysis of these Quaternary marine sapropels yields information about transport and sedimentation of pollen in the sea, and the geographic origin of such pollen. It is an excellent tool for datation which also allows reconstruction of the history of the original vegetation in the coastal areas, the history of the vegetal extinctions during the Quaternary, and the climatic evolution. The pursuit of these investigations appears extremely promising.

\section{CONCLUSIONS}

It is hoped that this preliminary study will show the great impact of marine palynology on studies of this particular geographical area. Thanks to the geobotanical differences between the northern and southern shores of the eastern Mediterranean the origin of the pollen can indeed be pointed out. The distribution of the pollen provides information on the processes of pollen transport and sedimentation. This, in turn, is related to the tracing of the terrigenous sediments once they reached the sea, to the movements of the water masses, and to the tectonic history of the sea-bottom.

Palynological long-distance correlations appear possible thanks to the widespread, non-localized character of the marine pollen spectra, even though the variety of places of origin of the pollen results in a recognizable sedimentation gradient. The marine pollen spectra is believed to represent 
partly the vegetation of the littoral areas. It keeps track of the global variations in altitude of the different vegetal belts, allowing one to attempt to describe the climatic history. The progressive extinctions of the Tertiary relics through the Quaternary finally provides a chronology for dating even isolated samples such as those studied here. Indeed, this preliminary study calls for further research in this field, and already gives assurance of great interest.

\section{ACKNOWLEDGMENTS}

The author, who has been supported by the Centre National de la Recherche Scientifique, Paris, France, wishes to thank the Lamont-Doherty Geological Observatory of Columbia University, Palisades, New York, and the Department of Geology, Imperial College, London, for providing her with their laboratory facilities. She thanks also W. B. F. Ryan for reading and editing the manuscript, and providing the available sedimentology and lithology information on the samples used in this study.

\section{RESUME}

Sept niveaux très riches en matière organique provenant de quatre forages profonds en Méditerranée Orientale ont été analysés: deux au Sud et Sud-ouest de la Grèce, deux au Nord de l'Egypte.

Les spectres polliniques se rangent en deux catégories, où dominent, dans l'une, les apports des rivages Nord de la Méditerranée, dans l'autre, les apports du Nil.

La première catégorie groupe les types phytogéographiques suivants: arbres méditerranéens (Pinus, Cedrus, Quercus, Olea), arbres décidus thermophiles (Fagus, Acer, Castanea, Alnus, Ostrya, Corylus, Carpinus, Carya, Pterocarya, Juglans, Engelhardtia, Tilia, Liquidambar, Ulmus, Zelkova, Fraxinus), arbres divers (Tsuga, Abies, Betula), buissons (Ericacées, Thyméléacées, Buxus, Poterium, Пlex, Myrica) et parmi les herbacées, Artemisia, et un cortège de familles diverses. Les apports du Nil comprennent Graminées, Cypéracées, Ptéridophytes, hydrophytes, arbres et herbacées tropicales. Tous les échantillons proches de la Grèce, et le niveau supérieur d'un des deux forages proches de l'Egypte, appartiennent à la première catégorie. Les apports du Nil se trouvent dans les trois autres échantillons proches de l'Egypte.

Les Chénopodiacées, également représentées partout, semblent résulter d'une pluie pollinique assez constante, répartie sur toute la surface de la mer, sans doute après un long transport aérien dans la haute atmosphère. Elles peuvent provenir des zones steppiques et désertiques d'Afrique, ou du Moyen-Orient.

Les pollens nord-méditerranéens auraient subi d'abord un bref transport aérien depuis leur végétation d'origine, située, semble-t-il, dans la région côtière d'Italie du Sud, de Grèce et de Turquie, y compris les premières zones montagneuses de l'arrière-pays, jusqu'à la surface de la mer à proximité du rivage. Ils flottent ensuite à la surface, et se comportent alors comme des éléments pélagiques. Leur sédimentation ne dépend pas de la topographie du fond marin, mais plutôt de la distance des côtes, des courants, des vents.

$\mathrm{Au}$ contraire, la sédimentation des pollens d'origine nilotique dépend de la topographie du fond marin. Cela suggère qu'ils se comportent comme des éléments benthiques, transportés peu au-dessus du fond marin avec la charge sédimentaire minérale du fleuve. Le nombre de pollens par gramme de sédiment est beaucoup plus élevé pour les échantillons à dominante pélagique (jusqu'à 32000 ), que pour les benthiques (en moyenne 2000).
Une chronologie est rendue possible par la présence-ou l'absence-dans les échantillons d'influence nordique, de pollens d'arbres appartenant à une flore relictuelle tertiaire, vivant encore en Europe du Sud, Italie surtout, Grèce, Espagne, au début du Pléistocène: Pterocarya, Carya, Tsuga, Juglans, Liquidambar, Zelkova, Cedrus, Pinus haploxylon. Presque toute cette flore s'est éteinte progressivement au cours du Quaternaire. Un âge Pliocène est exclu par l'absence de Nyssa, Sciadopitys. Les âges proposés pour les divers échantillons d'influence nordique vont du Villafranchien inférieur à l'Interglaciaire Mindel-Riss. Au moins une des reliques tertiaires, Cedrus, et peut-être aussi Zelkova, n'ont disparu du continent qu'à l'Holocène, sans doute sous l'influence de l'Homme.

Le paysage végétal dans la région cotière d'Italie méridionale, Grèce, et Turquie, s'est modifié par un déplacement vertical des zones de végétation qui apparaissent dans les spectres polliniques: la steppe à Artemisia au bord du rivage, dans les plaines côtières et sur les plateaux de l'arrière-pays, la forêt méditerranéenne sur les pentes basses et moyennes, dont les éléments les plus humides se mêlent vers les sommets avec les arbres décidus thermophiles qui nécessitent des pluies d'été. Dans ces régions méditerranéennes, le facteur climatique limitant est la pluviosité. Les variations de température ont une moindre influence.

L'extension de la steppe à Artemisia est ainsi attribuée surtout à une diminution de la pluviosité; de méme, la disparition progressive des arbres décidus thermophiles. Un retour de la forêt méditerranéenne dans le niveau le plus récent est attribué à une phase plus humide. La disparition antérieure des arbres décidus thermophiles les empêche de regagner du terrain.

L'analyse pollinique de ces sédiments organiques marins Quaternaires fournit donc des renseignements, à la fois sur le transport et la sédimentation polliniques en mer, sur l'origine géographique du pollen et sur celle des sédiments qui les recèlent; c'est un excellent outil de datation, qui permet en outre de retracer l'histoire de la végétation originelle dans les régions côtières, celle des extinctions végétales au cours du Quaternaire, ainsi que l'évolution climatique. La poursuite de ces recherches apparait comme extrêmement prometteuse.

\section{REFERENCES}

Diniz, F., 1967. Une flore tertiaire de caractère Méditerranéen au Portugal. Rev. Palaeobot. Palynol. 5, 263.

Emery, K. O., Heezen, B. C., and Allan, T. D., 1966. Bathymetry of the eastern Mediterranean Sea. Deep Sea Res. 13, 173

Koreneva, E. V., 1969. Palynological investigations of sediment cores from the Mediterranean Sea. In General problems of Micropalaeontology and organic sediments in Oceans and Seas, Nauka, Moscow, 268, (in Russian Engl. Summary).

Kuprianova, L. A., 1960. Palynological data contributing to the history of Liquidambar. Pollen Spores. 11 (1), 71.

Lona, F., 1950. Contributo alla storia della vegetazione e del clima nella Val Padana. Analisi polliniche del giacimento Villafranchiano di Leffe (Bergamo). Atti Soc. Ital. Sci. Nat. 89, 123.

1962. Prime analisi pollinologiche sui depositi Terziari-Quaternari di Castell 'arquato: reperti di vegetazione da clima freddo sotto le formazioni calcaree ad Amphistegina, Boll. Soc. Geol. Ital. 81 (1), 89, (Res. Engl). 
1963a. Boschi di Cedrus e Sciadopitys in Emilia durante il Pliocene (Riassunto). Nuovo Giorn. Botan. Ital. 70, 573.

, 1963b. Alcune tipi di pollini fossili rinvenuti in depositi terziari del Piemonte (Riassunto). Nuovo Giorn. Botan. Ital. 70, 574.

Lona, F. and Follieri, M., 1958. Successione pollinica della serie superiore (Günz-Mindel) di Leffe (Bergamo). Veröff. Geobot. Inst. Rübel Zürich. 34, 86.

Lona, F. and Ricciardi, E., 1961. Studio pollinologico stratigrafico su una serie lacustre pleistocenica dell 'Italia centrale (Bacino di Gubbio, Perugia). Pollen Spores, Fr. 1, 93 (Res Fr.).

Mercier, J. and Sauvage, J., 1965. Sur la géologie de la Macédoine centrale: les tufs volcaniques et les formations volcano-détritiques plioènes à pollens et spores d'Almopias (Grèce). Ann. Géol. Pays Helléniques. 16, 188.

Napoleone, I. and Follieri, M., 1967. Pollen analysis of a diatomite near Mazzano (Rome). Rev. Palaeobotan. Palynol. 4 (1-4), 143.

Ricciardi, E., 1961a. Analisi pollinologica dei sedimenti lacustri lignitiferi di Pietrafitta (Perugia, Italia). Pollen Spores, Fr. 3 (2), 325 (Res. Fr.).

1961b. Considerazioni preliminari sui pollini fossili rinvenuti in un deposito lacustre Quaternario contenente materiali vulcanici (Gruppo Cimini-Sabatini). Boll. Soc. Geol. Ital. 80 (4), 129 (Res. Engl). 1965a. Pollini fossili terziari nell 'Italia del nord (Piemonte) e loro significato paleoclimatico. Bull. Soc. Geol. Ital. 82 (1), 111 (Res. Engl.).

1965b. Analisi polliniche di una serie stratigrafica dei sedimenti lacustri del Pleistocene inferiore nel bacino di Leonessa (Rieti, Italia centrale). B. Bot. Ital. 72 (1), 62 (Res. Engl.).

Rossignol, M., 1961. Analyse pollinique de sédiments marins quaternaires en Israël-1: sédiments récents. Pollen Spores. 3 (2), 303.
1969. Sédimentation palynologique dans le domaine marin quaternaire de Palestine: étude de paleo-environement. Notes Mém. Moyen-Orient, Fr., X, 273 p.

Rossignol, M. and Pastouret, L., 1971. Analyse pollinique de niveaux sapropéliques post-glaciaires dans une carotte en Méditerranée Orientale, Rev. Palaeobotan. Palynol. $11,227$.

Ryan, W. B. F., 1969. The deep-sea floor of the Mediterranean, PhD. Thesis, Columbia University, New York.

Tralau, H., 1963. Asiatic dicotyledonous affinities in the Cainozoic flora of Europe. Handl. Kgl. Svenska Vetenskapsakad. $4(9,3), 87$ p.

van der Hammen, T., Wijmstra, T. A., and van der Molen, W. H., 1965. Palynological study of a very thick peat section in Greece, and the Würm-glacial vegetation in the Mediterranean region. Geol. en Mijnbouw. 4437.

van Zeist, W., 1967. Late Quaternary vegetation history of western Iran. Rev. Palaeobot. Palynol., Nederl., 301.

Venkatarathnam, K. and Ryan, W. B. F., 1971. Dispersal pattern of clay minerals in the sediments of the eastern Mediterranean, Marine Geol. 11, 261.

Vronsky, V. A. and Panov, D. G., 1963. Composition and repartition of pollens and spores in the superficial layer of marine sediments of the Mediterranean Sea (in Russian). Dokl. Akad. Nauk, SSSR. 153 (2) 447.

Wijmstra, T. A., 1969. Palynology of the first 30 meters of a 120 meter deep section in Northern Greece. Acta. Bot. Neerl. 18 (4), 511, 527.

Zagwijn, W. H., 1960. Aspects of the Pliocene and early Pleistocene vegetation in the Netherlands. Mededelingen van de Geolog. Sticht. C, 111, 1, 5, Maastricht. $78 \mathrm{p}$.

Zohary, M., 1963. On the geobotanical structure of Iran. Bull. Res. Counc. Israel. 11 (D), (suppl.) 113 p. 


\section{PLATE 1}

Locations: Figures 1-6, 10, 11 (Sample 125-3-5); Figure 7 (Sample 128-3-6); Figures 8, 9 (Sample 130-2-3); Figures 12, 13 (Sample 131 A-4-2). Scales: 10 microns: A for Figures 1-4, 6, 11; B for Figures 5, 7, 10, 12, 13; C for Figures 8, 9 .

Figures 1,2, 5. Zelkova

Figures 3, 4, 6, 7. Ulmus

Figures 8,9. Olea

Figure 10. Cyatheaceae

Figure 11. Riccia

Figures 12,13. cf Hypoestes (Acanthaceae) 
PLATE 1
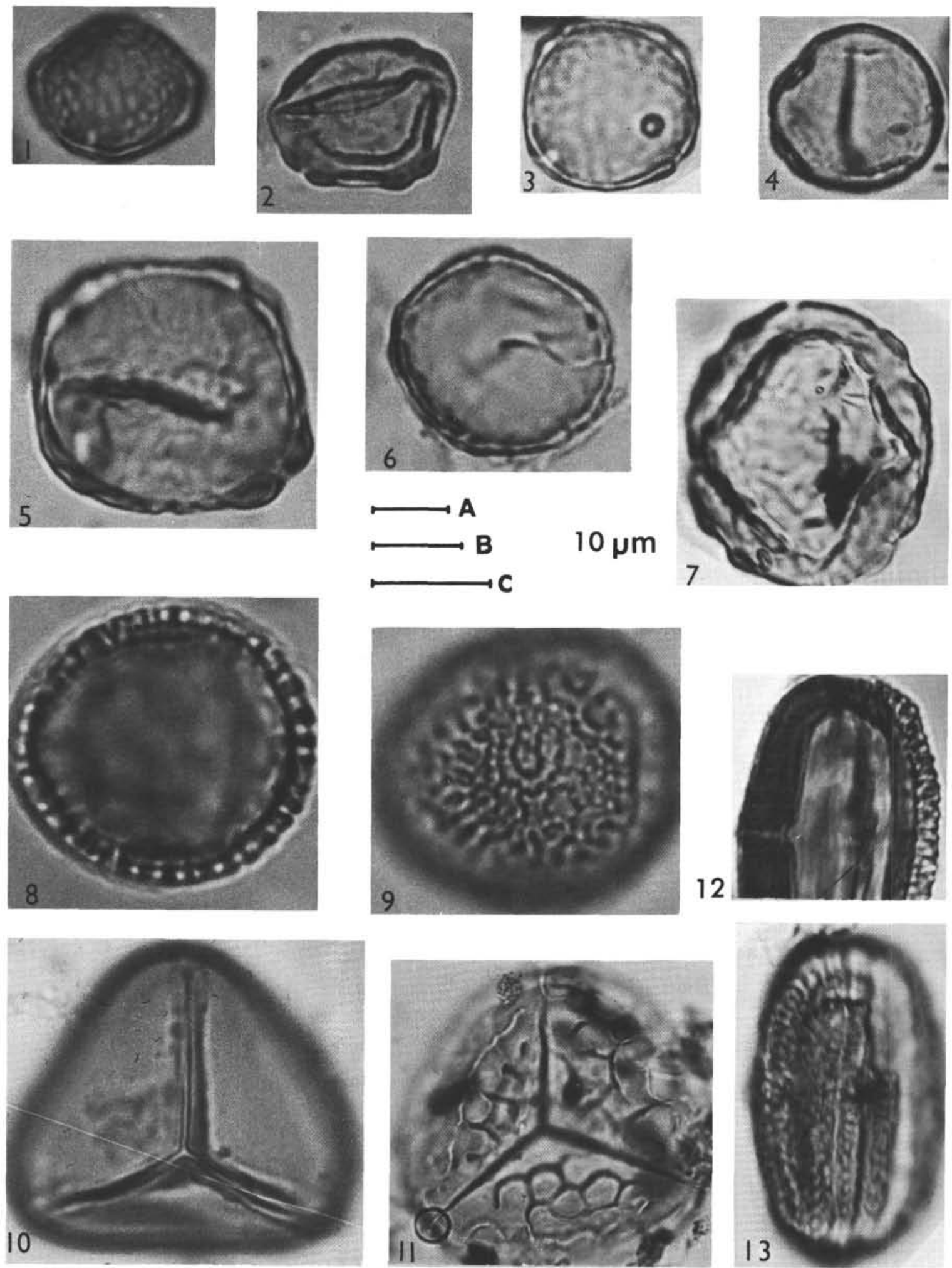
PLATE 2

Locations: Figures 1, 13, 16, 17 (Sample 130-2-3); Figure 3 (Sample 128-3-6); Figures 2, 4, 5, 6, 7, 8, 9, 10, 11, 12, 14, 15, 18 (Sample 125-3-5). Scales: 10 microns: A for Figures 2, 5, 6, 7, 8, 9, 15, 17; B for Figures 10, 11, 16, 18; C for Figures 12, 13; D for Figures 1, 3, 4, 14.

Figures 1,8. Corylus

Figure 2. Carpinus caucasica

Figures 3, 4. Betula

Figures 5, 10. Liquidambar

Figure 6. Ericaceae

Figure 7. Alnus

Figure 9. Ostrya

Figure 11. Rumex

Figure 12. Plantago

Figure 13. Poterium spinosum

Figure 14. Quercus

Figures 15, 17. Tsuga

Figure 16. Pinus haploxylon

Figure 18. Ostrya 
PLATE 2
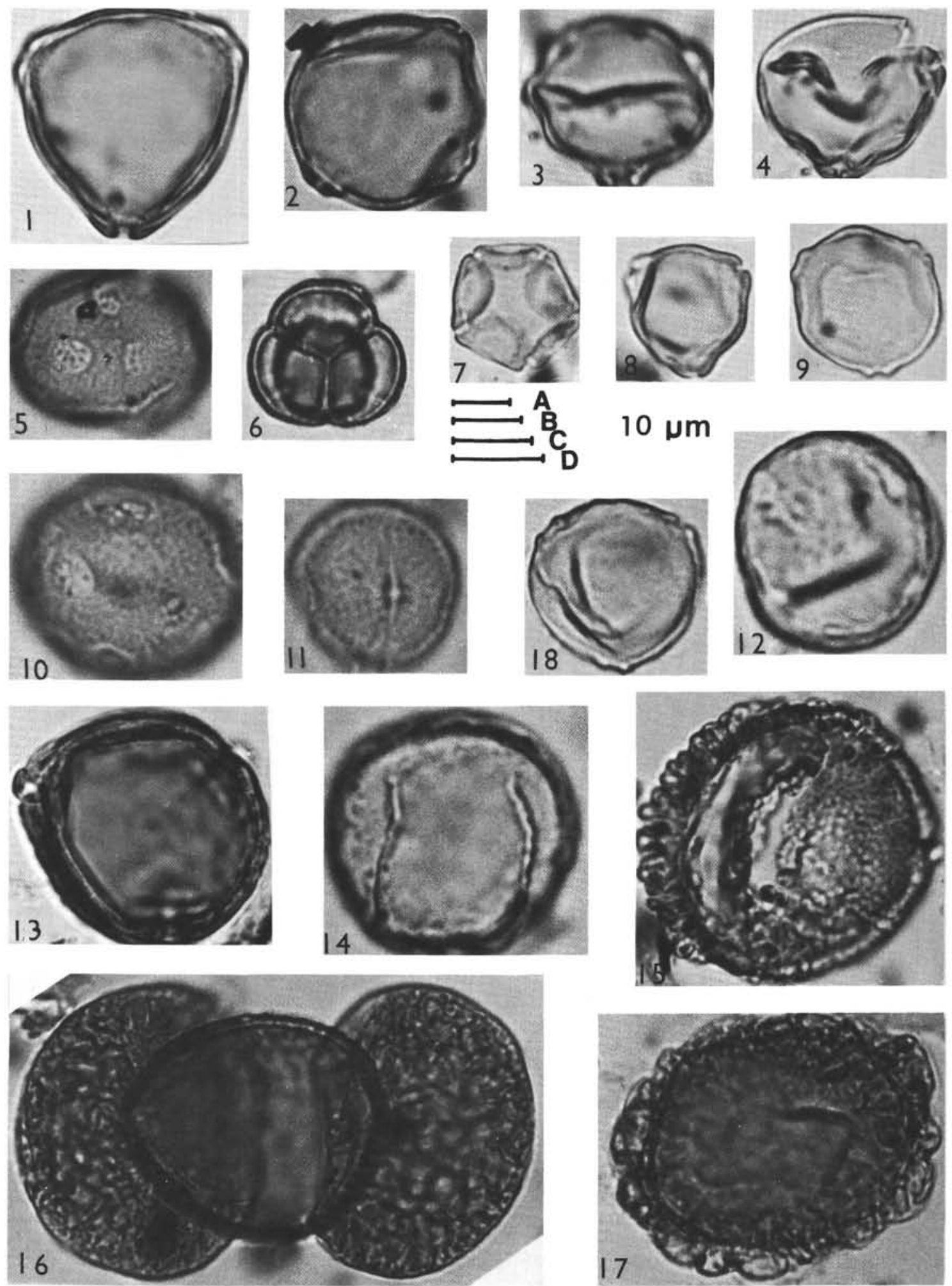


\section{PLATE 3}

All pollens are from Sample 125-3-5, except 5, 6 and 10 which are from Sample 130-2-3. Scale bar represents 10 microns.

Figures 1-6, 10. Unknown tricolporate pollen (see p. 10).

Figure 1. Polar contour.

Figure 2. Equatorial contour.

Figure 3. Polar exine.

Figure 4. Exo-and endoapertures.

Figures 5, 6, 7. Three different focusings of the same pollen, in oblique view.

Figure 5. Polar area, lower surface, with a colpus (vertical).

Figure 6. Mesocolpial and pericolpial areas, with a colpus (oblique).

Figure 7. Optical section. The three optical sections, Figures 1, 2. 10 show the strong columellation and the apparent absence of an endexine.

Figures 7,8. Carya

Figures 9,11. Pterocarya

Figure 12. Tilia 
PLATE 3
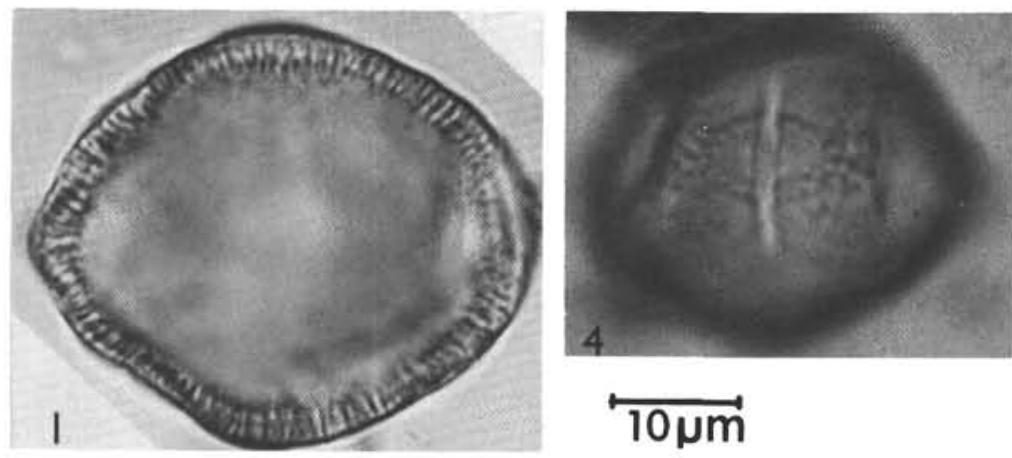

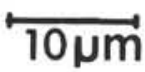
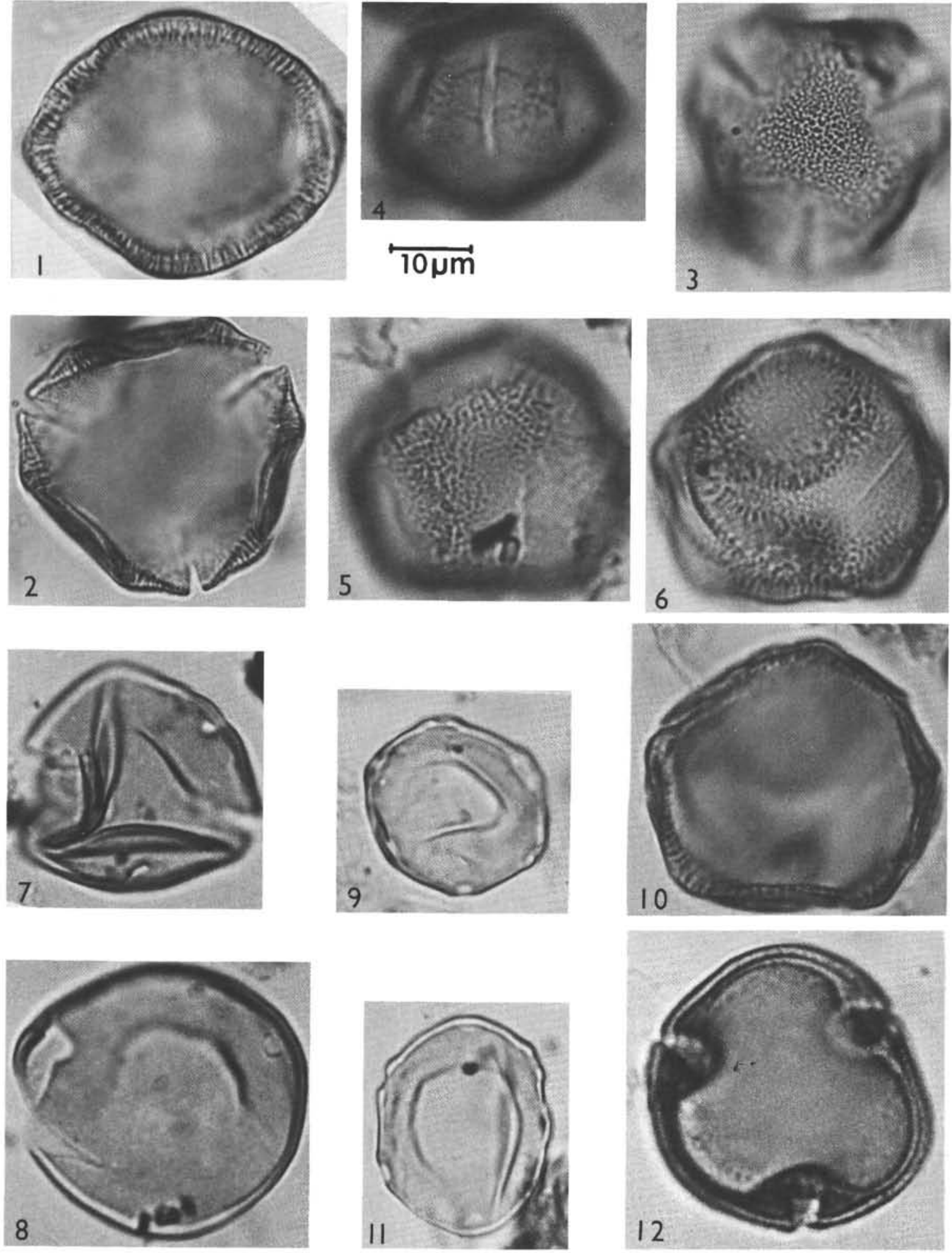